\title{
Financial Literacy Education in Ontario: An Exploratory Study of Elementary Teachers' Perceptions, Attitudes, and Practices
}

\author{
Gail E. Henderson \\ Queen's University \\ Pamela Beach \\ Queen's University \\ Andrew Coombs \\ Queen's University
}

\begin{abstract}
Politicians are pushing school boards to do more to ensure students leave school with the financial literacy skills they will need to navigate an increasingly complex financial marketplace. Financial literacy education must start early to achieve this goal, yet there has been


very little Canadian research on financial literacy education at the elementary level. This exploratory study used an anonymous, online survey to gain a preliminary understanding of full-time Ontario elementary teachers' perceptions, attitudes, and practices with respect to financial literacy education. Respondents overwhelmingly favour teaching financial literacy in elementary school. Almost half of respondents currently incorporate financial literacy into their classroom practice. These teachers rely primarily on free, online resources. With respect to barriers to teaching financial literacy, respondents cited the lack of an appropriate curriculum and lack of support from schools and school boards. Respondents identified professional development as the main type of support they would like to see schools and school boards provide to support them in teaching financial literacy going forward.

Keywords: financial literacy, financial education, elementary teachers

\section{Résumé}

Les politiciens poussent les conseils scolaires à en faire davantage pour s'assurer que les étudiants finissent leurs études avec les compétences financières dont ils auront besoin pour naviguer sur un marché financier de plus en plus complexe. Bien qu'il faille commencer tôt pour atteindre cet objectif, il existe très peu de recherches canadiennes sur l'éducation financière au primaire. Cette étude exploratoire a utilisé un sondage anonyme en ligne pour obtenir une compréhension préliminaire des perceptions, attitudes et pratiques des enseignants à temps plein du primaire en Ontario quant à l'éducation financière. Les répondants sont très majoritairement favorables à l'enseignement de la littératie financière au primaire, et près de la moitié d'entre eux l'intègrent déjà dans leur pratique en classe. Ces enseignants ont principalement recours à des ressources en ligne gratuites. Les répondants mentionnent l'absence d'un programme d'études approprié et le manque de soutien de la part des écoles et des conseils scolaires comme des obstacles à l'enseignement de la littératie financière. Les répondants ont identifié le développement professionnel comme principal type de soutien qu'ils souhaiteraient voir les écoles et les conseils scolaires leur apporter afin de les aider à enseigner la littératie financière dans l'avenir.

Mots-clés : littératie financière, éducation financière, enseignants du primaire 


\section{Introduction}

A half-century ago, most Canadians were able to rely on an employer-sponsored pension plan and government benefits to provide a decent income in retirement. The small percentage of students who pursued post-secondary education benefited from low tuition, which was heavily government-subsidized. Unfortunately, many Canadians no longer experience this level of financial security. Today, responsibility for funding retirement and post-secondary education, in Canada and internationally, has shifted from employers and government to individual families, while the cost of post-secondary education continues to rise (Henderson, 2019; Organisation for Economic Co-operation and Development [OECD], 2017b). This shift to individual responsibility does not negate the societal interest in attaining a post-secondary education and the ability of individuals and families "to provide for themselves throughout their lives" (Fanto, 1998, p. 138). In addition to the economic benefits, an increasing number of studies link financial well-being to physical and mental health (Roberts et al., 2000; Sturgeon et al., 2016; Sweet et al., 2013).

In our current low-interest rate environment, generating a sufficient return on savings to cover the rising costs of post-secondary education and retirement requires families to navigate an increasingly complex financial marketplace (OECD, 2016; Ontario Ministry of Education, 2016a). The recent COVID-19 pandemic is also negatively affecting families' income and wealth (Angus Reid Institute, 2020). Unfortunately, many individuals lack the requisite "financial literacy," or knowledge of and ability to apply financial concepts, to navigate the private financial marketplace and public government benefits successfully (Lusardi \& Mitchell, 2014; Ontario Ministry of Education Working Group on Financial Literacy, 2010; Task Force on Financial Literacy, 2010). In a 2016 survey, only $39 \%$ of Canadian adults were able to correctly answer questions on both simple and compound interest (OECD, 2017a). In a separate survey of 5,000 Canadians focused on investment knowledge, 51\% failed a general investment knowledge test (Innovative Research Group, 2017). This issue is not unique to Canada, as other G20 countries report similarly low levels of financial literacy (OECD, 2017a).

Provincial and federal governments have responded to concerns about Canadians' inadequate financial literacy. All provinces and territories (except New Brunswick and the Northwest Territories) include, or have plans to include, financial literacy in the official school curricula, with some provinces expanding financial literacy initiatives and 
curriculum within $\mathrm{K}-12$ schooling. Individual schools are also implementing their own initiatives (CBC News, 2020). Ontario formally introduced financial literacy into the curriculum in 2011, when the province published its first "scope and sequence of expectations" document for financial literacy (Ontario Ministry of Education, 2011). The updated scope and sequence document, published in 2016, acknowledges the importance of financial literacy for Ontario's students (Ontario Ministry of Education, 2016a). The Ontario government's 2019 budget discusses taking steps to improve financial literacy education in the school system (Government of Ontario, 2019). ${ }^{1}$ However, financial literacy in curriculum documents and financial literacy in the classroom are two different things, and the latter does not always follow from the former (McGregor, 2018).

Notwithstanding the political attention to financial literacy education, there have been few Canadian academic empirical studies on the subject, and prior studies have tended to focus on the secondary or post-secondary school level (e.g., Visano \& Ek-Udofia, 2017). The purpose of this exploratory study was to gain a preliminary understanding of full-time Ontario elementary teachers' perceptions, attitudes, and practices with respect to financial literacy education. We focus on elementary school teachers given the consensus in the relevant literature, discussed below, that financial literacy education must start early if it is to achieve its goal of improving individuals' financial decision making throughout their lifetimes. We focus on teachers, rather than school board or ministry administrators, based on Ontario curriculum documents in place at the time, which provide relatively little guidance to teachers in the form of specific expectations. Data generated on teachers' perceptions, attitudes, and practices can help to inform future policy, curricula development, and professional development in this area.

1 Since this article was accepted for publication, the Ontario Ministry of Education introduced a new math curriculum, which includes mandatory financial literacy education from Grades 1 to 8 . The 2016 scope and sequence document remains in place. See Ontario Ministry of Education (2020). 


\section{Literature Review}

\section{Financial Literacy: Definition, Perceived Benefits, and Policy Responses}

The final report of the Canadian federal Task Force on Financial Literacy defines financial literacy as "having the knowledge, skills and confidence to make responsible financial decisions" (Task Force, 2010, p. 10). This definition is similar to those used by other organizations and governments (e.g., Council of Ministers of Education, Canada [CMEC], 2017; Exec. Order No. 13646, 2013; OECD, 2016). The "core" of financial literacy relates to personal finances (Amagir et al., 2018). The Ontario Ministry of Education Working Group on Financial Literacy (2010) noted the importance of focusing on this core content.

The Ontario definition is similar, but adds an additional element that appears to be unique. The "vision" articulated by the Ontario Ministry of Education Working Group on Financial Literacy (2010), and repeated in Ministry of Education curriculum documents, is that "Ontario students will have the skills and knowledge to take responsibility for managing their personal financial well-being with confidence, competence, and a compassionate awareness of the world around them [emphasis added]" (p. 4). Although this awareness is arguably necessary to mitigate the otherwise highly individualistic bias of financial literacy education (Henderson et al., 2020), as described in more detail below, this additional element is more prominent in the curriculum than the personal finances core.

A common element of the various definitions is the ability to apply appropriate financial knowledge to financial decisions in daily life, including decisions that involve interacting with the financial services industry. It is the application piece that separates financial literacy from associated skills such as numeracy. Canadian results from the Organisation for Economic Co-operation and Development (OECD) Program for International Student Assessment (PISA) study of 15-year-olds found that although students' performance in math, reading, and science is associated with performance in financial literacy, "students who do well in the other domains will not necessarily do well in financial literacy: the financial literacy assessment also captures unique skills not measured in other domains" (CMEC, 2017, p. 4). The OECD (2017b) reports that across countries that participate in PISA for financial literacy, "around $38 \%$ of the variation in financial literacy 
scores reflects factors that are uniquely captured by the financial literacy assessment" (p. 68). The remaining variation is explained by differing results in math and reading.

Financial literacy is correlated with positive financial behaviours such as having a bank account, planning for retirement, and lower levels of debt (OECD, 2017a). Students who scored well on financial literacy in the OECD PISA test, discussed further below, were more likely to say that they would save up for something they wanted but did not have the money for, rather than trying to borrow money from family or friends (OECD, 2017b). Financial literacy is thought to make it easier for individuals to navigate an increasingly complex financial marketplace, although this notion is contested by some legal scholars (Bramley, 2012; Willis, 2008). For example, financial literacy is thought to enable individuals to accurately assess and compare the cost of credit products and to avoid financial abuse (Expert Committee to Consider Financial Advisory and Financial Planning Policy Alternatives, 2016; OECD, 2017a). Governments also have asserted a connection between a financially literate population and stable financial markets and healthy national economy (Exec. Order No. 13646, 2013; OECD, 2016; Task Force on Financial Literacy, 2010; Williams, 2007).

The perceived benefits of financial literacy have resulted in actions by Canadian governments, including federal and provincial financial literacy strategies, aimed at improving Canadians' levels of financial literacy (Autorité des Marchés Financiers, 2019; Financial Consumer Agency of Canada [FCAC], 2015a; Government of Ontario, 2019). The report of the Ontario Ministry of Education Working Group on Financial Literacy (2010) includes a review of actions in other jurisdictions. One prominent strategy is integrating financial literacy education into the school curriculum (OECD, 2017b). Delivering financial literacy education in the formal school system can help to alleviate differences in financial literacy based on socio-economic characteristics and close the large gap in financial literacy scores between the top and bottom students (CMEC, 2017; Fanto, 1998). Canada has endorsed the OECD's high-level principles on national strategies for financial education, which include "ensur[ing] financial education is included in the school curricula" (McGregor, 2018). 


\section{Financial Literacy and Youth}

Proponents and critics of financial literacy agree that if it is to lead to desirable changes in financial behaviour (e.g., saving more), then it must start early (Bramley, 2012; Exec. Order No. 13646, 2013; FCAC, 2015a; McCormick, 2009; OECD, 2016; Ontario Ministry of Education Working Group on Financial Literacy, 2010; TD Canada Trust, 2015; Waldron, 2011). Prior studies have found that by the time students engage with financial literacy curriculum at the secondary level, "habits are formed and social and familial influences have already taken hold" (Batty et al., 2015, p. 71). The OECD notes that "efforts to improve financial knowledge in the workplace or other settings can be severely limited by a lack of early exposure to financial education" (OECD, 2016, p. 83). Students are also having to make financial decisions at a younger age and are likely to face a more complex financial marketplace than their parents, which means that they require the knowledge, skills, and confidence to make financial decisions earlier than in the past (McGregor, 2018; OECD, 2017b). For example, over 70\% of Canadian students who participated in PISA hold a bank account, a level which is probably similar to earlier generations, but approximately $15 \%$ have a prepaid debit card, which is a relatively new financial product (OECD, 2017b). While having a bank account is strongly correlated to higher financial literacy scores, having a prepaid debit card is not (OECD, 2017b). Canadian students who hold a bank account are also more likely to be working a part-time job outside of school hours (OECD, 2017b), which also necessitates making financial decisions about saving and spending, with potential long-term implications. Research to date on the relationship between earning money from "small jobs" and financial literacy is inconclusive, but the PISA results do not suggest that students who are earning money in various ways (doing chores at home, informal jobs, or part-time jobs) score better on the test (OECD, 2017b). On the other hand, receiving money as a gift is associated with higher scores, even controlling for differences in socio-economic status.

Although there is some evidence that financial literacy education improves knowledge of financial matters and positively affects financial behaviour (e.g., opening a bank account), the methodologies employed in existing studies limit these findings. In their study that captured the voices of 14 youths who participated in a savings program, Hamilton and her colleagues (2012) found that participants viewed the program as highly beneficial. While this study was limited by the self-reports and interviews, data 
showed that access to financial literacy material and course instructors could positively affect financial decisions. In a randomized controlled study of students in Grades 4 and 5 , Batty and his colleagues (2015) found a statistically significant increase in knowledge for students who received financial literacy education integrated into the existing curriculum, rather than as a standalone class, and a statistically significant but smaller effect on attitudes and behaviour (Batty et al., 2015). They noted, however, the lack of studies tracking students who have received financial literacy education to determine its impact on financial decision making over the long-term. The OECD noted that more evidence is needed to demonstrate whether integrating financial literacy in existing subjects is more effective than a standalone course (OECD, 2017b). A recent literature review of studies of financial literacy education programs for children in Ghana, South Africa, and the United States echoed this finding (Amagir et al., 2018). Their analysis of these studies of eight financial education programs in primary schools found that while general positive effects on financial knowledge and attitudes were found, the long-term impact was difficult to assess. In a meta-analysis of 188 articles that presented results from financial education studies, Miller and colleagues (2015) found that financial literacy education was more likely to have a positive impact on some areas (e.g., increasing savings) than others (e.g., credit default). Most of the studies they reviewed, however, lacked empirical methods, skewing the credibility of the findings (Miller et al., 2015).

\section{OECD PISA Study Results}

The OECD PISA financial literacy framework assesses 15-year-old students in four areas, listed in descending order of weight on the test: "money and transactions, planning and managing finances, risk and reward and the financial landscape" (OECD, 2016, p. 80). Data using this framework were first collected in 2012; seven Canadian provinces, including Ontario, participated for the first time in 2015. In 2015, all seven Canadian provinces scored above the OECD average, with a small range of variation between provinces. Less encouragingly, 13\% of Canadian students scored below Level 1 proficiency, meaning that they "are not yet able to apply their knowledge to real-life situations involving financial issues and decisions" (OECD, 2017b, p. 76). Level 2 is considered the baseline at which students can not only identify financial terms, products, and documents, but also begin to apply financial concepts. At Level 4, students can understand what 
we might consider basic financial products and concepts, such as compound interest in savings products, perform essential financial tasks, such as comparing loan products, and take into account long-term consequences of their financial decisions. Only 46\% scored within the range for Level 4. Level 5 students can "analyze complex financial products" and "solve non-routine financial problems" (OECD, 2017b, p. 73). Twenty-two percent of Canadian students achieved scores within this highest level.

Gaps in financial literacy also may exacerbate pre-existing income and wealth inequalities (OECD, 2017b). With respect to Canada's PISA scores, only in Prince Edward Island did socio-economic status and having a parent who attended university not make a difference to test scores (CMEC, 2017), although again there is less of a gap in scores based on socio-economic status in Canada than in other OECD countries (OECD, 2017b). PISA results internationally, however, show that scores vary more widely within countries, including Canada, than between countries, and that this variation is explained by differences in socio-economic status (OECD, 2017b). This is troubling, because students who come from economically disadvantaged backgrounds have a lower margin of error for financial mistakes than their better-off peers. As noted above, students who score below Level 1 on the PISA scale lack the ability to apply their financial knowledge to real-life financial decisions.

\section{Incorporating Financial Literacy in the School Curriculum}

Canada's national financial literacy strategy endorses the view that financial literacy education should start early, but offers little guidance on how to integrate financial literacy into elementary school classrooms (FCAC, 2015a). The Ontario Ministry of Education Working Group on Financial Literacy notes that most jurisdictions introduce financial literacy into the curriculum in Grade 4 (Ontario Ministry of Education Working Group on Financial Literacy, 2010). McGregor's (2018) study of consumer education curricula, which included financial literacy education, reviewed curricula starting in Grade 7 but found that most consumer education content was offered in Grade 12.

Ontario's approach to financial literacy education at the elementary level is similar to Canadian jurisdictions other than Quebec in attempting to integrate financial literacy into existing subjects and disciplines, rather than offering a standalone, mandatory financial literacy course. Ontario teachers are expected to make connections to financial 
literacy in all subjects, starting in Grade 4, but how they do so is left up to the individual teacher. Suggestions for financial literacy "learning opportunities" connected to each of the subjects are set out in the Ontario Scope and Sequence of Expectations for Financial Literacy (Ontario Ministry of Education, 2016a). Unlike other curricula documents, this does not set out the respective responsibilities of students, parents, teachers, and principals, nor overall or specific expectations related to financial literacy alone, although some learning opportunities are tied to specific expectations in other curricula. Financial literacy is also mentioned in the $\mathrm{K}-8$ curricula for French as a Second Language (Ontario Ministry of Education, 2013), Health and Physical Education (Ontario Ministry of Education, 2019), and Social Studies, Grades 1-6; History and Geography, Grades 7-8 (Ontario Ministry of Education, 2018). These documents refer teachers to the learning opportunities set out in the Scope and Sequence document. Financial literacy skills are not among the expectations set out in these curricula. The French as a Second Language curriculum suggests financial issues as a topic for practicing oral and written communication. The Health and Physical Education curriculum contains references to financial problems and financial stresses arising from addiction, not disclosing financial information to others online, and financial barriers to participation in physical fitness activities. Although the Mathematics curriculum (Ontario Ministry of Education, 2005; revised) does not expressly reference financial literacy, both specific expectations and sample problems relate to financial literacy. Specific expectations from Grades 1 through 5 relate to representing money amounts. In Grades 6-8, financial literacy topics can be found in the sample problems, most of which focus on "spending." For example, sample problems relating to solving problems involving percentages ask students to calculate sales tax. The sample problem for modelling linear relationships, a Grade 8 expectation, involves the calculation of compound interest earned on money invested in a bank certificate, but demonstrating an understanding of compound interest is not a specific expectation. However, understanding compound interest is considered a requirement for financial literacy (OECD, 2017a). The Ontario Ministry of Education website also refers teachers to resources in EduGAINs (Ontario Ministry of Education, n.d.).

As noted above, the definition of financial literacy adopted by the Ontario Ministry of Education includes having "the skills and knowledge to take responsibility for managing their personal financial well-being with confidence [and] competence," but adds that students should also do so with a "compassionate awareness of the world around 
them" (Ontario Ministry of Education, 2016b, p. 21). The Scope and Sequence document seems to focus primarily on this additional aspect of the definition through learning opportunities that relate primarily to collective economic relationships, such as trade relationships between nations, and collective impacts of economic policies or practices, such as environmental harm. Although curriculum documents assert that "in order to make wise choices, [students] will need to understand how [economic] forces affect their own and their families' economic and financial circumstances" (Ontario Ministry of Education, 2016b, p. 21), the teacher prompts in the financial literacy Scope and Sequence document do not demonstrate how these forces affect personal financial decision making. The learning opportunities in the Scope and Sequence document also relate primarily to related, transferable skills in "problem solving, inquiry, decision making, critical thinking, and critical literacy" over those related more specifically to financial literacy, such as "saving, spending, borrowing, and investing" (Ontario Ministry of Education, 2016a, p. 3 ). For example, many of the teacher prompts relate to interpreting messages in the media and advertisements.

Beyond official curriculum documents, financial literacy education resources for teachers have been created by other government agencies, such as the provincial securities commissions (Autorité des Marchés Financiers, n.d.; Manitoba Securities Commission, n.d.), and financial services companies (VISA, 2009). The Canadian Financial Literacy Database, maintained by the Financial Consumer Agency of Canada (FCAC), also contains resources for teachers (FCAC, n.d.). The OECD notes that even among jurisdictions that include financial literacy in school curricula, "almost none of them specifically assess financial literacy skills" (OECD, 2017b).

Successfully integrating financial literacy education into existing curricula, however, requires overcoming existing barriers, including teachers' lack of training, background, and confidence in this area (Ontario Ministry of Education Working Group on Financial Literacy, 2010; President's Advisory Council on Financial Capability, 2013; TD Canada Trust, 2015). Prior studies note a lack of research on teacher training (Henning \& Lucey, 2017) and professional development (McCormick, 2009; OECD, 2017b) with respect to financial literacy. In a US-wide survey of $\mathrm{K}-12$ teachers commissioned by the US accounting firm and consultancy PricewaterhouseCoopers (PwC), the top four barriers to teaching financial literacy cited by respondents were lack of appropriate curriculum (78\%), lack of qualified teachers (69\%), lack of financial materials to share with parents 
or guardians $(68 \%)$, and the view that financial literacy is not critical to preparing students for college (62\%; PwC, 2016).

As summarized above, the literature suggests that financial literacy education may improve financial decision making later in life, but that it must start early if it is to do so. The PISA results suggest that financial literacy does not necessarily follow from strong math and reading skills; rather, it is a unique skillset that must be taught separately. Little is known, particularly in Canada, about the extent to which teachers are in fact integrating financial literacy education into their classroom practice and how they are doing so. This exploratory study seeks to gain a preliminary understanding of Ontario elementary classroom teachers' perceptions, attitudes, and practices with respect to financial literacy education. These findings will help to inform curriculum and professional development initiatives in this area, as well as future research, as Ontario and other provinces seek to further develop their financial literacy curriculum.

\section{Method}

\section{Financial Literacy Education Survey}

A survey method was used to gain a preliminary understanding of full-time Ontario elementary teachers' perceptions, attitudes, and practices with respect to financial literacy education. The survey was online and anonymous. Data were collected through Qualtrics, an online survey platform. All data collection procedures received university and school board ethics clearance. Requests for ethics approval to circulate the survey were sent to nine school boards in Ontario, both public and Catholic, over a period of several months. School boards were selected based on two main criteria: whether the study fit within the school board's current research policy, and the geographic location of the school board. The latter criterion was relevant because the survey asked teachers if they would be willing to meet for a follow-up in-person study (Beach et al., 2020). The survey was ultimately circulated to teachers of five school boards, including both public and Catholic. The survey was sent to all of the principals of two school boards and a select number 
of principals of two others ${ }^{2}$ to circulate to their teachers. Fourteen principals confirmed that they circulated the survey to their teachers. The fifth school board chose to post it to their website. Additional participants were recruited through social media (Facebook and Twitter), but, based on the timing of completed surveys, this recruitment method was less successful than circulation of the survey by principals.

Due to differences in timing of submission to and responses from school boards regarding ethics approval, the survey was sent to the first group of principals in October 2017 and to the last group in April 2018. It was posted to the school board website in March 2018. The survey was left open until June 2018. We decided to keep the survey open for several months in order to increase the number of respondents.

The survey used in this study was based on a nationwide survey of US K-12 teachers commissioned by PwC (2016). The survey in the current study included the three demographic questions from the PwC survey (i.e., grades currently taught, age, and gender) and one additional question (How long have you been teaching?). Gender of the teacher is relevant to studies of teachers' perceptions, attitudes, and practices with respect to financial literacy education due to evidence of differences in levels of financial knowledge based on gender (OECD, 2017a), although the most recent PISA test of 15-year-old students indicates that this gap may be closing (CMEC, 2017). For questions involving grade level (i.e., What grade(s) do you currently teach? When is the best time to teach students financial literacy? and When does your school or school board begin teaching students basic financial literacy today?), we allowed respondents to select a specific grade or grades, rather than choosing a range (e.g., "Grade 1" rather than "kindergarten-3rd grades"). Unlike the PwC survey, we did not ask about province/state, subject taught, or job description, since our survey was limited to Ontario full-time elementary teachers. The potential correlation between subject areas taught and teachers who are currently incorporating financial literacy is discussed in Results and Study Limitations, below.

The survey for our study included the same five items related to teachers' perceptions and attitudes on financial literacy education as the PwC study (e.g., When is the best time to teach students financial education?), and eight items related to current practices

2 Limiting circulation to a smaller number of principals was a condition of receiving ethics approval from the school boards for the study. 
and challenges (e.g., In what ways does your school or district support educators who teach financial education?), including two questions not asked in the PwC study. We were also interested in who (individual, company, non-profit, or government) produces the resources that teachers are using. In addition, three open-ended questions were also added to the PwC survey questions; two for respondents who currently incorporate financial literacy into their teaching practice and one for all respondents: If yes, how do you incorporate financial literacy education into your program? What factors motivate you to choose a particular resource? and Is there anything else you would like to add about financial literacy education?

\section{Data Analysis}

For questions with categorical responses, we used frequency counts, contingency tables, and Pearson's chi-square tests to determine if there were statistical differences between demographic groupings. For questions with continuous responses, means and standard deviations were calculated and analysis of variance was used to determine if there were statistical differences between demographic groupings. All data analysis was completed using Statistical Program for Social Sciences version 22 (SPSS v. 22).

Following the quantitative analysis, open-ended survey responses were analyzed through an inductive approach (Thomas, 2006). Responses to the three open-ended survey questions were first read reflectively to gain a general sense of participants' views. Text segments were then unitized into meaningful phrases and coded for potential categories. Codes and categories were reviewed to reduce redundancy and checked for relevance with respect to the research questions and in support of the quantitative results.

\section{Results}

In total, 157 respondents completed the survey. Respondents in the final sample included 91\% who identified as women and $9 \%$ who identified as men. This is not surprising since, according to Statistics Canada, in 2016, 84\% of all elementary school teachers in Canada were women (Statistics Canada, 2018). Participants were fairly evenly distributed by age, years of experience, and grades taught (i.e., pre-kindergarten to Grade 8). The most common age range and years of experience selected were $35-39$ years of age (23.6\%) and 
6-10 years of experience (22.4\%). The most common grades taught were Grades 4, 5, and 6 (at $8.3 \%$ each), and pre-kindergarten and kindergarten (7.7\%). Although our survey did not ask teachers about subjects taught, with respect to grades taught, respondents were asked to select all that apply. Seven respondents selected every grade. There was a general lack of significant correlation between demographic variables (i.e., age, experience, grades taught) and perceived benefits, challenges, actual and desired support, and other variables that were explored in this study.

With respect to their attitudes about financial literacy education, participants overwhelmingly supported the inclusion of financial literacy in classroom instruction as either the primary $(37.5 \%)$ or secondary $(55.4 \%)$ source of financial literacy education for students in addition to the home. Only two respondents thought teaching financial literacy should be done exclusively at home. These results are similar to the $\mathrm{PwC} \mathrm{K}-12$ United States survey. While there was disagreement on which grade represented the best time to introduce financial literacy education (e.g., 19.0\% in Grade 1, 15.9\% in Grade 6), 93.7\% agreed that financial literacy education should begin prior to Grade 7. This is also consistent with the PwC survey, in which $67 \%$ of respondents agreed that financial literacy should begin in elementary school (PwC, 2016). Unlike the PwC study, our results did not appear to depend on the age of the teacher. As noted above, the Ontario curriculum for financial literacy begins at Grade 4. Thirty-seven percent of teachers selected Grade 4.

A likely reason for such widespread support for developing students' financial literacy are the extensive benefits it is perceived to offer to students. As seen in Table 1, all 19 benefits listed as possible answers were endorsed by at least a third of participants. Interestingly, the lowest endorsed item (improved future strength of the economy) was the only item that did not directly benefit individual students. While one teacher saw no benefit to students receiving financial literacy education, the average teacher selected 12.5 of the 19 options, signifying teachers' views that financial literacy education provides a broad range of individual benefits for students. The most popular responses relate to the core skills associated with financial literacy named in Ontario curriculum documents, namely saving, spending, and borrowing. The low total number of endorsements for "learn to invest" (60) likely reflects the proportion of respondents who teach in the lower elementary grades. The additional transferable skills that were included in the survey list, namely "better decision-making" and "critical thinking," were also highly endorsed. Two respondents supplied open responses. One wrote in "problem solving," which is one of 
the related transferable skills mentioned in the Ontario Scope and Sequence document. The other wrote "all of the above."

\section{Table 1}

Benefits of Financial Literacy Education for Students

\begin{tabular}{rr}
\hline \multicolumn{1}{c}{ Benefit } & Frequency \\
\hline Learn to budget/money management & 150 \\
Learn the value of money & 137 \\
Basic handling of money & 137 \\
Understand debt & 132 \\
Plan for/prepare for the future & 129 \\
Learn personal responsibility & 127 \\
Better decision-making & 122 \\
Math literacy & 122 \\
Learn to use and understand common financial tools & 112 \\
Critical thinking & 107 \\
Financial stability/security & 96 \\
Practical knowledge & 92 \\
Learn independence & 88 \\
Build confidence in themselves & 82 \\
Learning skills & 77 \\
Improved future strength of the economy & 75 \\
Interpret personal financial documents & 61 \\
Improved quality of life & 65 \\
Learn to invest & 60 \\
Nothing/no/none & 1 \\
\hline
\end{tabular}

Of the 157 classroom teachers who completed the survey, just under half (49.0\%) currently incorporate financial literacy into their teaching practice. The fact that this number is much higher than the representative sample surveyed in the PwC K-12 United States survey (12\%) might reflect some self-selection bias in our sample (PwC, 2016). The actual percentage of Ontario teachers integrating financial literacy is likely much 
lower. Interestingly, no statistical differences were noted between the incorporation of financial literacy into teaching practice of teachers below Grade 4 and those teaching Grade 4 to $8\left(52.6 \%\right.$ and $47.9 \%$, respectively; $\left.\mathrm{X}^{2}[2,157]=.258, p=.611\right)$, even though Ontario's financial literacy curriculum in place at the time only started in Grade 4. This result differs from an earlier national study that found very few teachers below Grade 6 were involved in teaching financial literacy (TD Canada Trust, 2015), but again, this may be the result of differences in how participants were recruited for the studies. Also, given that $91 \%$ of respondents identified as women, our results counter potential concerns that differences in levels of financial literacy between men and women in the general population are affecting willingness to teach financial literacy in schools.

The qualitative analysis revealed that teachers who indicated that they incorporate financial literacy into their practice reported doing so through real-life math problems involving money, role play, budgeting for trips and classroom purchases, reward systems, and guest speakers. The most popular topic revealed in these responses was budgeting and/or knowing how much things cost. A small number specifically discussed saving, borrowing, and interest. Overall, responses related more to the core, personal finance content of financial literacy than to understanding of broader economic forces and collective economic relationships. Several of the respondents emphasized how realistic activities engage students in learning about financial literacy. This suggests that teaching practice mirrors the definition and goals of financial literacy as applying knowledge to real-life decision making.

With respect to subjects taught, most of the 70 respondents who provided an explanation of how they incorporate financial literacy into their classroom practice linked this to math and/or specific expectations of the math curriculum, such as learning about coins and money, but many also appear to go beyond specific curricula expectations. Three respondents reported it was incorporated into teaching French. Only one specifically referenced health, although several mentioned connecting financial literacy to healthy eating (e.g., cost of healthy food). Two respondents mentioned social studies and history.

The survey also asked participants who currently incorporate financial literacy into their teaching practice where they find and how they choose resources for use in their classrooms. Most teachers who accessed support for teaching financial literacy did so through free online resources $(20 \%)$, purchased resources with personal funds $(7 \%)$, or collaborated with other teachers $(5 \%)$. Use of free online resources was also the most 
popular source of resources for US teachers (PwC, 2016). Resources produced by companies $(12 \%)$ and individuals $(8 \%)$ were more commonly used than those produced by the Ministry of Education (4\%) and non-profit organizations (3\%), although most respondents to this question did not know or were unsure of who produced the resources they used $(22 \%)$. Teachers indicated various factors that motivate them to choose particular resources, including ease of use, accessibility, cost, visual appeal, interactivity, and relevance to real-life situations and to student needs.

Survey responses point to two possible contributing factors for not integrating financial topics into teaching practice. First, teachers indicated a wide range in the level of comfort they had in teaching financial literacy; responses to a 7-point Likert scale question indicated that teachers were only slightly comfortable $(M=3.31, S D=2.35)$ teaching financial literacy topics. Interestingly, the high standard deviation was not due to differential effects of teachers' years of experience $(F[4,151]=.853, p=.494)$ or grade division taught (i.e., jr./sr. kindergarten, Grades 1-3, Grades 4-6, Grades 7-8; $F[3,153]$ $=2.108, p=.102)$. Lack of comfort teaching financial literacy was also noted in the PwC $\mathrm{K}-12$ United States survey (PwC, 2016). A second possible contributing factor was the lack of support and professional development for teachers in integrating financial literacy topics into their instruction. As shown in Table 2, teachers identified a lack of an appropriate curriculum ( $43 \%)$ as the primary challenge to effectively teaching students financial literacy, which is consistent with the PwC K-12 United States survey. Teachers also identified not knowing where to find financial resources as a challenge (14\%). Interestingly, despite the lack of comfort teaching financial literacy, "need for qualified teachers" was identified by only two respondents. In contrast, $69 \%$ of respondents to the PwC K-12 United States survey cited a lack of qualified teachers as a "top challenge" (PwC, 2016, p. 5). The other two top challenges identified in the PwC K-12 United States survey, namely a need for resources to share with parents and a perception that financial literacy is not critical to preparing students for college, were seen as less important barriers. 
Table 2

Challenges that Limit Teachers Effectively Teaching Students Financial Literacy

\begin{tabular}{rc}
\hline \multicolumn{1}{c}{ Challenges } & Frequency \\
\hline Don't know where to find financial literacy resources & 22 \\
Isn't viewed as a critical skill for college and career readiness & 18 \\
Need take home financial literacy materials to share with parents & 14 \\
Too many financial literacy resources available/don't know which to use & 3 \\
Need qualified teachers & 2 \\
\hline
\end{tabular}

Teachers identified multiple avenues of support for incorporating financial literacy into their teaching practice. Table 3 illustrates the substantial difference between the actual and desired support for teachers from their school/school board. With respect to actual support, only $6 \%$ of teachers were able to identify types of school/school board support, while $64 \%$ of teachers were not aware if there was any offered, and $29 \%$ answered "none of the above." Teachers also identified not knowing where to find financial literacy resources as a challenge (14\%). Teachers have a strong desire for more support from schools and school boards, including access to financial literacy resources (34\%) and professional development support (46\%). These results, including the disparity between desired support for resources and professional development and what is actually provided, are similar to those in the PwC K-12 United States survey.

\section{Table 3}

Actual and Desired Support from School/School Board for Teachers Who Teach Financial Literacy

\begin{tabular}{rcc}
\hline \multicolumn{1}{c}{ Type of Support } & Actual & Desired \\
\hline Curriculum plans/course materials for financial literacy & & \\
units/courses & 5 & 54 \\
Professional development for teaching financial literacy & 1 & 33 \\
Release time for professional development & 0 & 33 \\
Funds to attend professional development & 1 & 7 \\
Other & 2 & 11
\end{tabular}




\begin{tabular}{rrcc}
\hline Type of Support & Actual & Desired \\
\hline & None of the above & 46 & --- \\
& Don't know/not sure & 100 & --- \\
\hline
\end{tabular}

\section{Discussion}

The purpose of this study was to gain a preliminary understanding of Ontario elementary teachers' perceptions, attitudes, and practices with respect to financial literacy education. The online, anonymous survey conducted for this study indicates a strong level of support among Ontario elementary teachers for teaching financial literacy at the elementary level.

With respect to perceived barriers to further incorporation of financial literacy into teachers' practices, respondents cited a lack of an appropriate curriculum and lack of support from schools and school boards for teaching financial literacy. The core concepts of financial literacy relate to personal finance. Our survey results indicate that this is what Ontario elementary teachers understand financial literacy to mean. As noted above, the learning opportunities set out in the Ontario Scope and Sequence document are more likely to emphasize learning about broader economic forces than personal finance, and are more likely to relate to applicable but transferable skills, such as critical literacy, than specific knowledge and skills around saving, spending, and borrowing. A shift in emphasis in curriculum documents could not only respond to this concern, but also improve results for students. As the PISA results, discussed above, show, high scores in math, reading, and science do not necessarily result in levels of financial literacy that will give students the competence and confidence to navigate the financial world. Teachers may also be struggling with the lack of specific expectations in the Scope and Sequence document.

The main type of support from schools and school boards that respondents would like to see is professional development. This expressed desire for professional development in financial literacy is consistent with the findings of previous reports and studies (TD Canada Trust, 2015), including the Ontario Ministry of Education Working Group on Financial Literacy (2010). A lack of progress on this front may reflect a peak of momentum on this topic in the immediate aftermath of the financial crisis, which has since waned. The current high level of support among survey participants for delivering 
financial literacy education through the formal education system indicates that teachers would reward efforts by the ministry, school boards, and schools to support teachers in incorporating financial literacy into their classroom practice through curriculum reform and professional development opportunities.

Interestingly, our preliminary results indicate that demographics do not appear to be among the barriers to integrating financial literacy into classroom practices. While surveys of adults generally have found lower levels of financial literacy among women, the high percentage of participants who self-identified as women $(91 \%)$ did not correspond to a low percentage of participants currently integrating financial literacy into their practice, nor did grade level taught or years of experience predict likelihood of doing so. More research is needed, however, to see if other differences among teachers, such as level of education attained, affect which teachers would be comfortable incorporating financial literacy into their teaching practice if required to do so, and which teachers have already done so.

The fact that respondents who are integrating financial literacy education into their teaching practice are doing so through real-life math problems, role play, and other similar methods means that they are demonstrating the practical usefulness of financial literacy to their students, which should help students not only to engage with this material (Ontario Ministry of Education Working Group on Financial Literacy, 2010), but also to develop those practical financial literacy skills that are independent of literacy, numeracy, and other related skills. This should increase the likelihood that their financial literacy education at the elementary level will positively affect their financial decision making as teenagers and young adults.

\section{Study Limitations and Future Directions}

The purpose of this exploratory study was to fill a gap in the research on financial literacy education at the elementary level. This exploratory study is significant for its preliminary insights into Ontario elementary teachers' perceptions, attitudes, and practices with respect to financial literacy education. It is important to consider our findings, however, in relation to our study's limitations. Both results and limitations can help other researchers in articulating research questions for further, more in-depth studies. 
First, our sample was drawn from one educational jurisdiction, Ontario. Although our sample drew from both public and Catholic school boards, and respondents recruited from social media could have included teachers in the private school system, we did not ask teachers for this information. Sampling participants from diverse educational contexts would allow for more situated and nuanced understandings of teachers' perceptions, attitudes, and practices with respect to financial literacy education, and to compare these to differences among provinces in levels of financial literacy among students. Second, individuals self-selected to participate in our study, which may have resulted in less moderate perceptions, attitudes, and practices with respect to financial literacy, as individuals who are already enthusiastic about financial literacy would likely be more motivated to share them than otherwise. Third, our study used a self-report measure, which relies upon teachers' perceptions of financial literacy education support and resources, rather than the actual support and resources that may or may not be available to them.

One potential area of future research is whether level of education makes it more likely that a teacher will incorporate financial literacy education into their teaching practice. Our survey did not ask respondents about their highest level of education. Research suggests a correlation between financial literacy and level of education, at least when it comes to saving (FCAC, 2015b). This also suggests that helping teachers improve their own financial literacy might result in more teachers incorporating financial literacy education into their classroom practice. As noted above, a majority of Canadian adults do not understand basic financial and investment concepts, and over half of the respondents to the survey were "slightly uncomfortable" to "extremely uncomfortable" teaching financial literacy. As one respondent noted in describing incorporating budgeting into his classroom practice, "I...wish I'd been taught myself in elementary."

\section{Conclusion}

In the past decade, governments have increased their efforts to improve individuals' levels of financial literacy. Government strategies emphasize the importance of the formal education system in improving financial literacy (FCAC, 2015a; President's Advisory Council on Financial Capability, 2013). Financial literacy as a solution to problems such as rising income and wealth inequality tends to be politically popular, appealing to both 
ends of the political spectrum (Willis, 2008). This means that pressure on educators to integrate financial literacy into the curriculum is more likely to increase than it is to wane. Despite this continuing emphasis, existing Canadian research on financial literacy education in the formal school system, particularly at the elementary level, is limited. Although further research is necessary, this exploratory study of Ontario elementary teachers' perceptions, attitudes, and practices with respect to financial literacy provides some preliminary insight into teachers' openness to this new area of the curriculum, perceived barriers to incorporating financial literacy into their practice, and support they would like to see from school boards to help them to do so. These preliminary results can help to guide further, more focused research into this important, emerging subject area. 


\section{References}

Amagir, A., Groot, W., Maassen van den Brink, H., \& Wilschut, A. (2018). A review of financial-literacy education programs for children and adolescents. Citizenship, Social and Economics Education, 17(1), 56-80.

Angus Reid Institute. (2020, March 25). COVID-19: Those least equipped to endure economic downturn bearing the brunt of layoffs. http://angusreid.org/ covid-19-economic-impact-canada/

Autorité des Marchés Financiers. (n.d.). Teacher zone. https://lautorite.qc.ca/en/ general-public/tes-affaires/teacher-zone/

Autorité des Marchés Financiers. (2019). Québec financial education strategy: 20192022 orientation and action plans. https://autorite.qc.ca/fileadmin/lautorite/ education-financiere/strategie-education-financiere-2019 an.pdf

Batty, M., Collins, J. M., \& Odders-White, E. (2015). Experimental evidence on the effects of financial education on elementary school students' knowledge, behavior, and attitudes. Journal of Consumer Affairs, 49(1), 69-96.

Beach, P., Henderson, G., \& McConnel, J. (2020). Elementary teachers' cognitive processes and metacognitive strategies during self-directed online learning. Teachers and Teaching, 26(5-6), 395-413.

Bramley, C. (2012). Addressing indebtedness in Canada: An evaluation of the final report by the Taskforce on Financial Literacy. Banking \& Finance Law Review, 27(4), $711-721$.

CBC News. (2020, February 20). A money fair at this St. John's school aims to make finance make 'cents'for students. CBC News. https://www. cbc.ca/news/canada/newfoundland-labrador/brother-rice-moneyfair-1.5470043?cmp=newsletter_CBC $\% 20$ News $\% 20$ Morning\%20 Brief $594 \quad 1239$

Council of Ministers of Education, Canada. (2017). Measuring up: Canadian results of the OECD PISA 2015 study: The performance of Canadian 15-year-olds in financial literacy. https://www.cmec.ca/docs/pisa2015/Highlights-PISA2015FinancialLiteracyReport-EN.pdf 
Exec. Order No. 13646, Establishing the president's advisory council on financial capability for young Americans. (2013). https://www.govinfo.gov/content/pkg/ DCPD-201300456/html/DCPD-201300456.htm

Expert Committee to Consider Financial Advisory and Financial Planning Policy Alternatives. (2016). Final report. https://www.fin.gov.on.ca/en/consultations/ fpfa/fpfa-final-report.pdf

Fanto, J. (1998). We're all capitalists now: The importance, nature, provision and regulation of investor education. Case Western Law Review, 49(1), 105-180.

Financial Consumer Agency of Canada. (n.d.). Canadian financial literacy database. https://www.canada.ca/en/financial-consumer-agency/services/financial-literacydatabase.html

Financial Consumer Agency of Canada. (2015a). National strategy for financial literacy - Count me in, Canada. https://www.canada.ca/en/financial-consumer-agency/ programs/financial-literacy/financial-literacy-strategy.html

Financial Consumer Agency of Canada. (2015b). Managing money and planning for the future: Key findings from the 2014 Canadian Financial Capability Survey - Final report. https:/www.canada.ca/content/dam/canada/financial-consumer-agency/ migration/eng/resources/researchsurveys/documents/managing-money-keyfindings.pdf

Government of Ontario. (2019). 2019 Ontario budget: Protecting what matters most. https://budget.ontario.ca/pdf/2019/2019-ontario-budget-en.pdf

Hamilton, L., Shobe, M., Murphy-Erby, Y., \& Christy, K. (2012). It's all about security to me: The role of environment in youth financial literacy and savings behaviors. SAGE Open, 2(4), 1-8.

Henderson, G. E. (2019). Group RESPs: The intersection of government support for education savings and securities regulation. University of Toronto Law Journal, $69(1), 44-84$.

Henderson, G. E., Beach, P., Sun, L., \& McConnel, J. (2020). Does the content of financial literacy education resources vary based on who made or paid for them? Citizenship, Social and Economics Education, 19(3), 192-210. 
Henning, M., \& Lucey, T. (2017). Elementary preservice teachers' and teacher educators' perceptions of financial literacy education. The Social Studies, 108(4), 163-173.

Innovative Research Group Inc. (2017). 2017 CSA investor index. Canadian Securities Administrators. https://www.securities-administrators.ca/uploadedFiles/Investor Tools/CSA07\%20Investor\%20Index\%20Deck\%20-\%20Full\%20Report \%20-\%20 20171128.pdf

Lusardi, A., \& Mitchell, O. S. (2014). The economic importance of financial literacy: Theory and evidence. Journal of Economic Literature, 52(1), 5-44.

Manitoba Securities Commission. (n.d.). Make it count: An instructor's resource for youth money management. Make it Count. http://www.makeitcountonline.ca/msc/ instructors/index_en.html

McCormick, M. H. (2009). The effectiveness of youth financial education: A review of the literature. Journal of Financial Counselling and Planning, 20(1), 70-83.

McGregor, S. L. T. (2018). Status of consumer education and financial education in Canada (2016). Canadian Journal of Education, 41(2), 601-632.

Miller, M., Reichelstein, J., Salas, C., \& Zia, B. (2015). Can you help someone become financially capable? A meta-analysis of the literature. The World Bank Research Observer, 30(2), 220-246.

Ontario Ministry of Education. (n.d.). Financial literacy education. EduGAINs. http:// www.edugains.ca/newsite/FinancialLit/index.html

Ontario Ministry of Education. (2005). The Ontario curriculum grades 1-8:

Mathematics. http://www.edu.gov.on.ca/eng/document/curricul/elementary/ math1-8e.pdf

Ontario Ministry of Education. (2011). The Ontario curriculum grades 4-8: Financial literacy, scope and sequence of expectations. EduGAINs. http://www.edugains.ca/ resourcesFL/Resources/Elementary/FinLitGr4to8.pdf

Ontario Ministry of Education. (2013). The Ontario curriculum: French as a second language. http://www.edu.gov.on.ca/eng/curriculum/elementary/fs118-2013curr. pdf 
Ontario Ministry of Education. (2016a). The Ontario curriculum grades 4-8: Financial literacy, scope and sequence of expectations. http://www.edu.gov.on.ca/eng/ document/policy/FinLitGr4to8.pdf

Ontario Ministry of Education. (2016b). Ontario schools, kindergarten to grade 12: Policy and program requirements. http://www.edu.gov.on.ca/eng/document/ policy/os/onschools_2016e.pdf

Ontario Ministry of Education. (2018). The Ontario curriculum: Social studies, grades 1-6; history and geography, grades 7-8. http://www.edu.gov.on.ca/eng/ Curriculum/elementary/social-studies-history-geography-2018.pdf

Ontario Ministry of Education. (2019). The Ontario curriculum: Health and physical education. http://www.edu.gov.on.ca/eng/Curriculum/elementary/2019-healthphysical-education-grades-1 to8.pdf

Ontario Ministry of Education. (2020). Ontario curriculum grades 1 to 8: Mathematics. https://assets-us-01.kc-usercontent.com/fbd574c4-da36-0066-a0c5849ffb2de96e/90439c6e-f40c-4b58-840c-557ed88a9345/The\%20Ontario\%20 Curriculum\%20Grades\%201\%E2\%80\%938\%20-\%20Mathematics, \%202020\%20 (January $\% 202021) . p d f$

Ontario Ministry of Education Working Group on Financial Literacy. (2010). A sound investment: Financial literacy education in Ontario schools. Ontario Ministry of Education. http://www.edu.gov.on.ca/eng/Financial_Literacy_Eng.pdf

Organisation for Economic Co-operation and Development. (2016). PISA 2015 financial literacy framework. In PISA 2015 assessment and analytical framework: Science, reading, mathematic and financial literacy. https://doi. org/10.1787/9789264255425-6-en

Organisation for Economic Co-operation and Development. (2017a). G20/OECD INFE report on adult financial literacy in G20 countries. https://www.oecd.org/daf/ fin/financial-education/G20-OECD-INFE-report-adult-financial-literacy-in-G20countries.pdf

Organisation for Economic Co-operation and Development. (2017b). PISA 2015 results (volume iv): Students'financial literacy. https://doi. org/10.1787/9789264270282-en 
President's Advisory Council on Financial Capability. (2013). President's advisory council on financial capability: Final report. U.S. Department of the Treasury. https://www.treasury.gov/resource-center/financial- education/Documents/ PACFC\%20final\%20report \%20revised\%2022513\%20(8)_R.pdf

PricewaterhouseCoopers US. (2016). Bridging the financial literacy gap: Empowering teachers to support the next generation. https://www.pwc.com/us/en/about-us/ corporate-responsibility/library/pwc-financial-education-report.html

Roberts, R., Golding, J., Towell, T., Reid, S., Woodford, S., Vetere, A., \& Weinreb, I. (2000). Mental and physical health in students: The role of economic circumstances. British Journal of Health Psychology, 5(3), 289-297.

Statistics Canada. (2018). Back to school...by the numbers. https://www.statcan.gc.ca/eng/ dai/smr08/2018/smr08_220_2018

Sturgeon, J. A., Arewasikporn, A., Okun, M. A., Davis, M. C., Ong, A. D., \& Zautra, A. J. (2016). The psychosocial context of financial stress: Implications for inflammation and psychological health. Psychosomatic Medicine, 78(2), 134-143.

Sweet, E., Nandi, A., Adam, E. K., \& McDade, T. W. (2013). The high price of debt: Household financial debt and its impact on mental and physical health. Social Science \& Medicine, 91, 94-100.

Task Force on Financial Literacy. (2010). Canadians and their money: Building a brighter financial future. EduGAINs. http://www.edugains.ca/resourcesFL/ Background/CanadiansAndTheirMoney-2011.pdf

TD Canada Trust. (2015). State of financial education in Canada, prepared by Canadian foundation for economic education. https://www.td.com/document/PDF/to-ourcustomer/TDReport-StateofFinancialEducationinCanada.pdf

Thomas, D. R. (2006). A general inductive approach for analyzing qualitative evaluation data. American Journal of Evaluation, 27(2), 237-246.

VISA. (2009). Lesson plans: Choices \& decisions. Practical Money Skills Canada. https://www.practicalmoneyskills.ca/foreducators/lessonplans/ 
Visano, B. S., \& Ek-Udofia, I. (2017). Inclusive financial literacy education for inspiring a critical financial consciousness: An experiment in partnership with marginalised youth. International Journal of Inclusive Education, 21(7), 763-774.

Waldron, M. (2011). Unanswered questions about Canada's financial literacy strategy: A comment on the report of the federal task force. Canadian Business Law Journal, 51(3), 361-379.

Williams T. (2007). Empowerment of whom and for what? Financial literacy education and the new regulation of consumer financial services. Law \& Policy, 29, $226-256$.

Willis, L. E. (2008). Against financial-literacy education. Iowa Law Review, 94, 197-285. 